\title{
Auto-compasiunea și auto-eficacitateaca - resurse personale în cazul terapeuților
}

\section{Raluca TRIFU ${ }^{1^{*}}$, Bogdana MICLEA ${ }^{2^{*}}$, Dana HERȚA ${ }^{3}$, Smaranda PUȘCAȘU ${ }^{4}$, Carolina BODEA-HATEGAN ${ }^{5}$, Horia COMAN $^{6}$}

\begin{abstract}
One of the special human qualities is the compassion shown towards our fellow, in special situations, people who live certain states determined by the moments of life they go through.

Self-compassion refers to the ability to show compassion, understanding and protection to oneself. It is operationalized by researcher Kristin Neff. Self-efficacy, proposed by Albert Bandura, refers to the perception of self and is related to the belief in one's own abilities, in one's own ability to solve situations.

The interest of the study aims the relationship between self-compassion and self-efficacy in the case of a distinct category, that of therapists, professionally faced with situations that require personal resources.

Methods: The level of self-compassion was assessed with the Self-Compassion Scale, 26 items, proposed by Kristin Neff. The level of self-efficacy was assessed using the New General Self-Efficacy Scale, the 8-item scale proposed by Gilad Chen \& co (2001). Both questionnaires were distributed electronically. The data obtained were statistically analyzed and interpreted.

Results: In the professional categories investigated, there are underline links and relations between the two constructs, with professional implications. The results show (1) Therapists have high values in assessing selfefficacy; (2) Therapists have high values of self-compassion; (3) Therapists have a high level of self-compassion and a low level of self-criticism as indicated by the self-compassion sub-scales; (4) There is a direct relationship between self-efficacy and self-compassion; (5) Therapists with high level of self-compassion also have a high level of self-efficacy (6) The level of self-efficacy is influenced by age and professional experience. (7) The level of self-compassion is influenced by age and professional experience
\end{abstract}

Conclusion: The two concepts discussed are important in relation to certain professional categories and under the auspices of situations considered stressful and with emotional burden.

Keywords: self compassion, self efficacy, personal resources, therapist resources, SelfCompassion Scale

\section{Introducere}

Una dintre calitățile umane deosebite este compasiunea manifestată față de semenii noștri aflați în situații deosebite, persoane care trăiesc anumite stări determinate de momentele de viață pe care le traversează. Paul Gilbert. anunța, încă din introducerea la cartea sa intitulată Compasiunea și mintea umană, faptul că definirea compasiunii poate să fie realizată în multe moduri, dar „esența sa este bunăvoința, cu o conștientizare profundă a propriei suferințe și a celei resimțite de alte ființe, însoțită de dorința și încercarea de a alina"(Gilbert, 2020 p.11). Interesul asupra compasiunii ca subiect de studiu a crescut semnificativ în ultimii ani, tot mai multe cercetări vizând înțelegerea conceptului, dar și a modului în care compasiune poate influența capacitatea oamenilor de a depăși dificultățile în viață, dar și de a crea sentimente de împlinire. În prezent cercetători cu interese diverse explorează 
importanța bunăvoinței și afecțiunii, precum și modalitățile prin care ele pot să fie valorificate. Începând din anii 2000 cercetătoare americană Kristin Neff a explorat, încadrat și cuantificat conceptul de compasiune raportat la propria persoană, teoretizând, operaționalizând și aplicând conceptul de auto-compasiune (K. Neff, 2003). Auto-compasiunea se referă la capacitatea de a manifesta compasiune, înțelegere și protecție către propria persoană. Manifestarea autocompasiunii are implicații asupra funcționalității și eficienței persoanei în relațiile sale $\mathrm{cu}$ societatea și în relațiile sale. Impactul aplicării auto-compasiunii a fost documentat prin numeroase studii de către autoare conceptului. Relația autocompasiunii cu trauma, stima de sine, starea de sănătate, funcționarea fiziologică, burn-out-ul, reziliența sunt doar câteva dintre relațiile studiate.

De interes pentru prezentul studiu este relația dintre autocompasiune și autoeficacitate, relație care anterior nu a fost explorată.

Auto-eficacitatea este un concept care se referă la perceperea propriei persoane și este legată de credința în propriile abilități, în propria capacitate de a rezolva probleme. Poate deține valențe pozitive și negative. Conceptul a fost propus de Bandura, A. într-o lucrare ce teoretiza și operaționaliza această idee(Bandura, 1997). Auto-eficacitatea, așa cum este prezentată de către Bandura (1997), reprezintă un set de judecăți, raționamente ce se leagă de capacitatea indivizilor de a iniția și a realiza o sumă de acțiuni, necesare pentru a atinge performanțe în diferite domenii de activitate. Auto-eficacitatea propusă de
Bandură trebuie privită în contextul teoriei social-cognitive. Unii autori atrăgeau atenția asupra diferențierii dintre auto-eficacitate legată de câmp, adică acea auto-eficacitate care are impact asupra unui comportament, în comparația cu auto-eficacitatea manifestată în domeniul profesional (Tăut \& Băban, 2008), iar alți autori propun o auto-eficacitate intracâmp, adică autoevaluarea abilităților în ceea ce privește menținerea unui model (Dijkstra \& De Vries, 200o).

Pornind de la conceptul teoretic propus de Bandura s-a ajuns la operaționalizarea şi măsurarea conceptului. Amintim în acest sens lucrările lui Bentz (Betz \& Klein, 1996) și mai recent Chen (Chen et al., 2001)

Întrucât la baza auto-eficacității se află individul și implicit relația acestuia cu comportamentul său și cu mediul înconjurător, percepția sinelui și a abordării sale devine semnificativă și poate avea implicații în procesele de aplicare a conceptelor psihologice la viața de zi cu zi, în vederea creșterii stării de bine și de performanță.

\section{Obiectivul studiului}

Interesul studiului rezidă în observarea relației dintre auto-compasiune și autoeficacitatea în cazul unei categorii distincte, cea a terapeuților, confruntați profesional cu situații care solicită resursele personale.

\section{Material și metodă}

\section{Instrumente}

Pentru evaluarea relației dintre autocompasiune și auto-eficacitate s-a folosit două chestionare diferite. Nivelul de autocampasiunea a fost evaluat cu scala SelfCompassion Scale (SAC) , 26 de itemi, 
propusă de Kristin Neff. Scala este disponibilă în limba engleză pe pagina web a autoarei (K. Neff, 2021). Scala cuprinde mai multe dimensiuni de evaluare a auto-compasiunii. Aceste vor fi prezentate în continuare

Tabel nr 1- Distribuția itemilor scalei SAC pe dimensiuni

\begin{tabular}{ll}
\hline \hline Dimensiune & Item reprezentativ \\
\hline \hline Self-Kindness & $5,12,19,23,26$ \\
\hline Self-Judgment & $1,8,11,16,21$ \\
\hline Common Humanity & $3,7,10,15$ \\
\hline Isolation & $4,13,18,25$ \\
\hline Mindfulness & $9,14,17,22$ \\
\hline Over-identified & $2,6,20,24$ \\
\hline SCS - Scor general & $\begin{array}{l}\text { Media cu cotare inversă } \\
\text { pentru Self-Judgment, } \\
\text { Isolation, Over- } \\
\text { identified }\end{array}$ \\
\hline \hline
\end{tabular}

Nivelul de auto-eficacitate a fost evaluat $\mathrm{cu}$ ajutorul New General Self-Efficacy Scale (SAC), scală în 8 itemi propusă de Gilad Chen\&co (2001). Ambele chestionare au fost distribuite electronic. Datele obținute au fost prelucrate și interpretate statistic.

\section{Metodă}

Pentru realizarea prezentului studiu s-a apelat la cele două instrumente de evaluare a auto-eficacității respectiv autocompasiunii. Pentru scala de autocompasiune (SAC) s-a solicitat și s-a primit în prealabil acordul autoarei pentru utilizarea scalei în scop de cercetare. Scala de evaluare a auto-eficacității a fost propusă de Gilad Chen\&co (2001) pe baza conceptului inițial a lui Albert Bandura. Scala de evaluare a auto-eficacității (SAE) este disponibilă prin platforma
SPARQtools pusă la dispoziție de Standford (SPARQtools, 2021).

SPARQtools sunt seturi de instrumente digitale care facilitează accesul la cercetare prin formate ușor de utilizat, pe care practicienii și educatorii le pot folosi în scopul măsurării schimbărilor psihologice, comportamentale și societale. Fiecare set de instrumente împărtășește materiale și resurse bazate pe dovezi care pot fi puse la dispoziție pentru a aborda probleme actuale cu care oamenii se confruntă în prezent. Chestionarul de evaluare a autoeficacității, intitulat în limba engleză New General Self-Efficacy Scale este un instrument din kit-ul intitulat Measuring Mobility Toolkit pus la dispoziției cercetătorilor în scop de cercetare și evaluare. Chestionarul propus de Chen și colaboratorii săi (Chen et al., 2001) evaluează un nivel general al autoeficacității percepute și reflectă capacitatea de a rezolva situații

Cele două instrumente de cercetare au fost traduse în limba română de către 2 traducători profesioniști, prin procedură de traducere și retraducere, și adaptate. Ambele chestionare au fost transpuse în format electronic distribute on line în grupurile de specialitate sau prin invitație de participare la studiu

Procedura ulterioară a presupus ca datele obținute au fost prelucrate și interpretate statistic în vederea observării unor posibile relații dintre SAE şi SAC.

\section{Participanți}

Participanții la studiu au fost un număr de 43 de terapeuți, de vârste diferite și cu competențe diferite, mai exact psihoterapeuți, psihopedagogi, terapeuți de limbaj, terapeuți specializați în 
domeniul îngrijirilor paliative, kinetoterapeuți. Distribuția a fost echilibrată, exceptând grupa de vârsta de peste 60 de ani care a avut doar un participant. Majoritatea participanților sau situat în intervalul de vârstă 41-50 de ani. Distribuirea participanților în funcție de vârstă este observabilă în graficul următor (figura nr. 1).

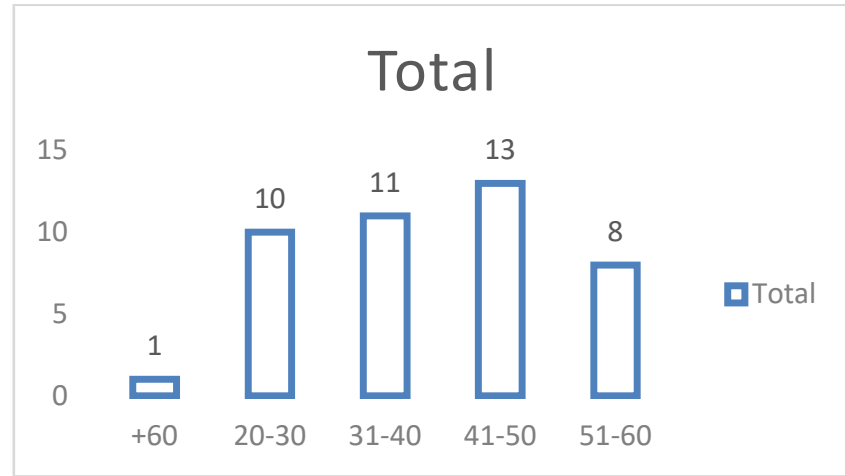

Figura nr 1. Distribuția lotului de participanți raportat la vârsta participaților

În ceea ce privește experiența profesională a participanților la studiu, majoritatea participanților se află deja în sectorul terapeuților cu experiență. Un număr relativ mare dintre participanți au o experiență profesională peste 5 ani. Distribuția experienței profesionale este prezentată în graficul următor(fig. nr.2).

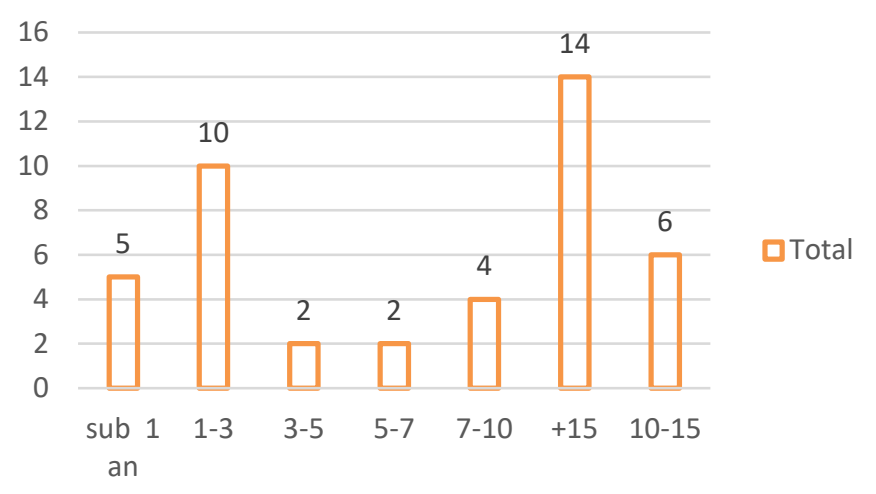

Figura nr. 2 - Distribuția lotului de participanți în funcție de experiența profesională.

\section{Rezultate}

Rezultatele obținute în urma prelucrărilor statistice indică valori diferite raportate la vârsta și experiența pe care terapeuții o au, dar și legături directe între cele două concepte, prin prisma raportării individuale și de grup. $\mathrm{Nu}$ a fost observată nicio diferență între scorurile obținute de terapeuți la scalele de auto-compasiune și auto-eficacitate, raportate la tipul de terapie practicat.

Astfel pentru scala de auto-eficacitate, valoarea minimă înregistrată a fost de 2.37, iar maximum de 4.87, cu o medie de 4.09 puncte. Acest lucru semnifică faptul că la nivelul grupului, nivelul de autoeficacitate perceput este crescut, dar că există și rezultate individuale care indică o percepție scăzută a propriei eficacități.

Tabel nr. 2. - Rezultatele obținute la scala auto-eficacitate - valori minime și maxime

Valori medii ale scalei de AE

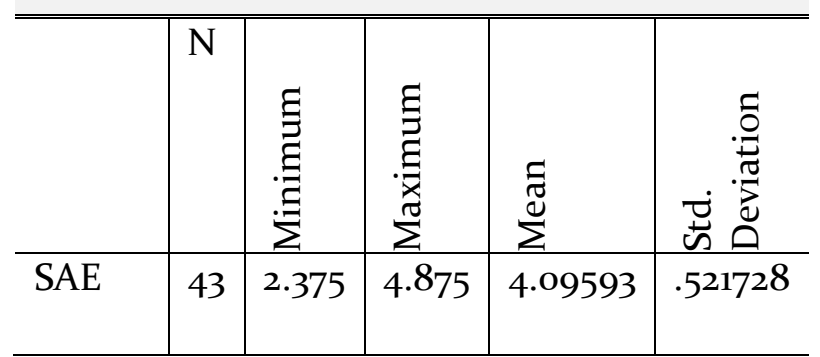

În ceea ce privește rezultatele obținute la scala de auto-compasiune putem observa scoruri crescute pentru dimensiunile $\mathrm{cu}$ valență pozitivă și scoruri scăzute la itemii cu valență negativă, notați cu ,- " în tabelul nr. 3. Este notabil faptul că terapeuții înregistrează un minimum de 1 pct pentru dimensiunile cu valență negativă de auto-critică $\mathrm{M}=2,367$ (SD \pm .868$)$, izolare $\mathrm{M}=2,36 \quad(\mathrm{SD} \pm .90)$ și supra-identificare $\mathrm{M}=2,79$ ( $\mathrm{SD} \pm .929)$, dar în același timp ating și un maxim de 4.4 (auto-critică) și 4.5(izolare) sau chiar 5.00 
(supra-identificare). În compensare, dimensiunile cu valență pozitivă înregistrează valori maxime la 2 din cele 3 dimensiuni, auto-compasiunea având însă cea mai mică valoare de 4.39 pentru palierul superior și o medie de $M=3.368$

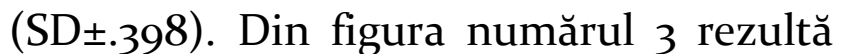
însă, așa cum era de așteptat că dimensiunile cu valență negativă sunt la praguri scăzute pe grafic, iar cele cu valență pozitivă sunt la nivel superior pe graficul (fig. nr. 3)

Tabel nr 3-Rezultatele obținute la scala de auto-compasiune, în funcție de medii și valorile prag

Valori medii ale SCS și factorilor SCS

\begin{tabular}{lllllll}
\hline & & $\mathrm{N}$ & Minimum & Maximum & Mean & Std. Deviation \\
\hline Self-Kindness & + & 43 & 2.0 & 5.0 & 3.670 & .6927 \\
\hline Self Judgement & - & 43 & 1.0 & 4.4 & 2.367 & .8684 \\
\hline $\begin{array}{l}\text { Common } \\
\text { Humanity }\end{array}$ & + & 43 & 1.00 & 5.00 & 3.6628 & .90778 \\
\hline Isolation & - & 43 & 1.00 & 4.50 & 2.3023 & .90724 \\
\hline Mindfulness & + & 43 & 2.00 & 5.00 & 4.0349 & .77648 \\
\hline $\begin{array}{l}\text { Over- } \\
\text { Identification }\end{array}$ & - & 43 & 1.25 & 5.00 & 2.7965 & .92944 \\
\hline $\begin{array}{l}\text { Auto- } \\
\text { compasiunea }\end{array}$ & + & 43 & 2.51 & 4.39 & 3.3688 & .39842 \\
\hline SAE & 43 & & & 4.09593 & .521728 \\
\hline \hline
\end{tabular}

\section{Relația dintre AE -SES}

Între rezultatele obținute la scala de auto-compasiune și scala de auto-eficacitate există o relație directă semnificativă statistic, $\mathrm{R}=.363, \mathrm{p}=0.05$ ( tab.nr. 4)

Tabel nr 4- Relația dintre auto-compasiune și auto-eficacitate în lotul de studiu

\begin{tabular}{llll}
\hline \hline & & Auto-eficacitatea & Auto-compasiunea \\
\hline \hline $\begin{array}{l}\text { Scala de auto- } \\
\text { eficacitate (SAE) }\end{array}$ & Pearson Correlation & 1 & $.363^{*}$ \\
\cline { 2 - 4 } & Sig. (2-tailed) & 43 & .017 \\
\cline { 2 - 4 } & $\mathrm{N}$ & 43 \\
\hline \multirow{2}{*}{ *. Correlation is significant at the 0.05 level (2-tailed). } & \\
\hline \hline
\end{tabular}

Din graficul nr. 4 se poate observa că la nivelul lotului studiat scoruri mai crescute au fost pe scala de auto-eficacite în comparație cu scala de auto-compasiune. 

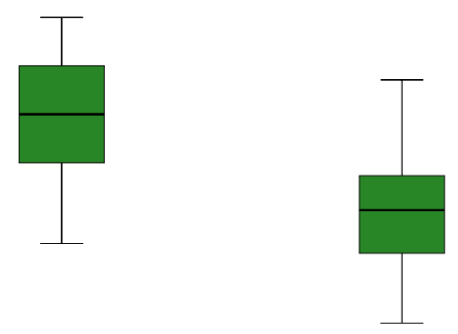

Figura $n r .4$ - Raportarea rezultatelor medii la SAC(scala de auto-compasiune) și SAE( scala de auto-eficacitate)

În evaluarea detaliată a relației dintre auto-eficacitate și fiecare dimensiune a scalei de auto-compasiune se poate observa din tabelul următor că scala de Tabel nr 5-Relația dintre auto-eficacitate și auto-compasiune și relația în interiorul scalei SAC

Relația SAE cu fiecare subscală SCS

\begin{tabular}{|c|c|c|c|c|c|c|c|c|}
\hline & & SAE & $\begin{array}{l}\text { Self- } \\
\text { Kindnes } \\
\mathrm{s}\end{array}$ & $\begin{array}{l}\text { Self } \\
\text { Judgeme } \\
\text { nt }\end{array}$ & $\begin{array}{l}\text { Commo } \\
\mathrm{n} \\
\text { Humanit } \\
\mathrm{y}\end{array}$ & $\begin{array}{l}\text { Isolatio } \\
\mathrm{n}\end{array}$ & $\begin{array}{l}\text { Mindfulne } \\
\text { ss }\end{array}$ & $\begin{array}{l}\text { Over- } \\
\text { Identificati } \\
\text { on }\end{array}$ \\
\hline \multirow[t]{3}{*}{ SAE } & $\begin{array}{l}\text { Pearson } \\
\text { Correlatio } \\
\mathrm{n}\end{array}$ & 1 & $.409^{* *}$ & -.236 & .073 & -.289 & $.386^{*}$ & $-.388^{*}$ \\
\hline & $\begin{array}{l}\text { Sig. (2- } \\
\text { tailed) }\end{array}$ & & .006 & .128 & .641 & .060 & .010 & .010 \\
\hline & $\mathrm{N}$ & 43 & 43 & 43 & 43 & 43 & 43 & 43 \\
\hline \multirow[t]{2}{*}{$\begin{array}{l}\text { Self- } \\
\text { Kindness }\end{array}$} & $\begin{array}{l}\text { Pearson } \\
\text { Correlatio } \\
\mathrm{n}\end{array}$ & $\begin{array}{l}.409^{*} \\
*\end{array}$ & 1 & $-.466^{* *}$ & $.531^{* *}$ & $-.326^{*}$ & $.728^{* *}$ & $-.418^{* *}$ \\
\hline & $\begin{array}{l}\text { Sig. (2- } \\
\text { tailed) }\end{array}$ & .006 & & .002 & .000 & .033 & .000 & .005 \\
\hline \multirow[t]{2}{*}{$\begin{array}{l}\text { Self } \\
\text { Judgement }\end{array}$} & $\begin{array}{l}\text { Pearson } \\
\text { Correlatio } \\
\mathrm{n}\end{array}$ & -.236 & $-.466^{* *}$ & 1 & .010 & $.588^{* *}$ & -.182 & $.692^{* *}$ \\
\hline & $\begin{array}{l}\text { Sig. (2- } \\
\text { tailed) }\end{array}$ & .128 & .002 & & .950 & .000 & .243 & .000 \\
\hline \multirow[t]{2}{*}{$\begin{array}{l}\text { Common } \\
\text { Humanity }\end{array}$} & $\begin{array}{l}\text { Pearson } \\
\text { Correlatio } \\
\mathrm{n}\end{array}$ & .073 & $.531^{* *}$ & .010 & 1 & .029 & $.688^{* *}$ & -.138 \\
\hline & $\begin{array}{l}\text { Sig. (2- } \\
\text { tailed) }\end{array}$ & .641 & .000 & .950 & & .853 & .000 & .378 \\
\hline
\end{tabular}

auto-eficacitate corelează puternic semnificativ cu dimensiune de selfkindness (bunătatea îndreptată către sine) Pearson Correlation $\mathrm{R}=.409^{* *}, \mathrm{p}=0.01$. și semnificativ statistic cu dimensiune de Mindfulness - Pearson Correlation $\mathrm{R}=$ $.386^{* *}, \mathrm{p}=0.05$. Este o relație indirectă, semnificativ statistic cu dimensiunea de Over-Identification (supra - identificare) Pearson Correlation $\mathrm{R}=.388^{*}, \mathrm{p}=0.01$. nesemnificativă statistic însă, cu Self Judgemen (auto-critica) R=-.236 și cu Isolation (izolarea) $\mathrm{R}=-.289$. Lipsit de relație statistică este și relația dintre SAE și Common Humanity (Umanintatea bazală) Auto-eficacitatea este în relație indirectă, 


\begin{tabular}{l|l|l|l|l|l|l|l|l}
\hline Isolation & $\begin{array}{l}\text { Pearson } \\
\text { Correlatio } \\
\mathrm{n}\end{array}$ & -.289 & $-.326^{*}$ & $.588^{* *}$ & .029 & 1 & -.214 & $.52^{* *}$ \\
\cline { 2 - 8 } & $\begin{array}{l}\text { Sig. (2- } \\
\text { tailed) }\end{array}$ & .060 & .033 & .000 & .853 & & .168 & .000 \\
\hline $\begin{array}{l}\text { Mindfulnes } \\
\mathrm{s}\end{array}$ & $\begin{array}{l}\text { Pearson } \\
\text { Correlatio } \\
\mathrm{n}\end{array}$ & $.386^{*}$ & $.728^{* *}$ & -.182 & $.688^{* *}$ & -.214 & 1 & -.297 \\
\cline { 2 - 8 } & $\begin{array}{l}\text { Sig. (2- } \\
\text { tailed) }\end{array}$ & .010 & .000 & .243 & .000 & .168 & & .053 \\
\hline $\begin{array}{l}\text { Over- } \\
\text { Identificati } \\
\text { on }\end{array}$ & $\begin{array}{l}\text { Pearson } \\
\text { Correlatio } \\
\mathrm{n}\end{array}$ & $-.388^{*}$ & $-.418^{* *}$ & $.692^{* *}$ & -.138 & $.592^{* *}$ & -.297 & 1 \\
\cline { 2 - 8 } & $\begin{array}{l}\text { Sig. (2- } \\
\text { tailed) }\end{array}$ & .010 & .005 & .000 & .378 & .000 & .053 & \\
\hline
\end{tabular}

**. Correlation is significant at the o.or level (2-tailed).

*. Correlation is significant at the 0.05 level (2-tailed).

\section{Relația auto-eficacitățiti și vârsta participanților}

Conform datelor rezultate scorurile de auto-eficacitate sunt influențate de vârsta persoanelor. Cele mai crescute scoruri la scala de evaluare a auto-eficacității au fost obținute de grupa de vârstă 51-6o de ani, iar cele mai scăzute scoruri au fost obținute de vârsta de grupă 20-30 de ani. Creșterea scorurilor la scala de autoeficacitate se face în mod progresiv de la vârstele tinere către vârstele mature.

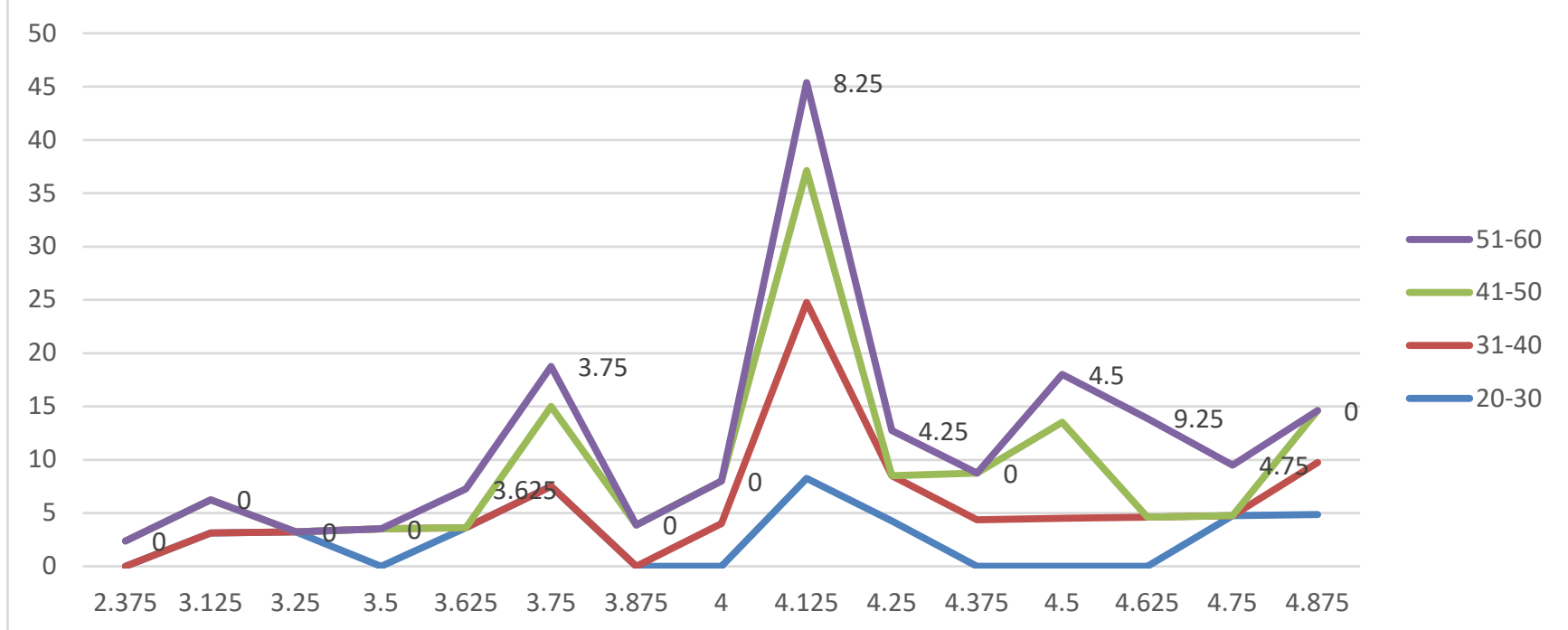

Figura nr 5- Rezultatele la scala de auto-eficacitate relaționate cu vârsta participanților la studiu.

Relația dintre auto-eficacitate și experiența profesională se păstrează ca și în cazul vârstei participanților. Cele mai crescute scoruri obținute prin instrumentul de evaluare a auto- eficacității sunt atribuite persoanelor care au o vechime în profesie de peste 15 ani, reliefate în graficul de mai jos prin culoarea orange (fig nr 6). Persoanele care au o vechime în profesie situată între 10-15 
ani au scoruri crescute la scala de autoeficacitate, iar terapeuții care sunt la început de carieră înregistrează o autoeficacitate mai scăzută.

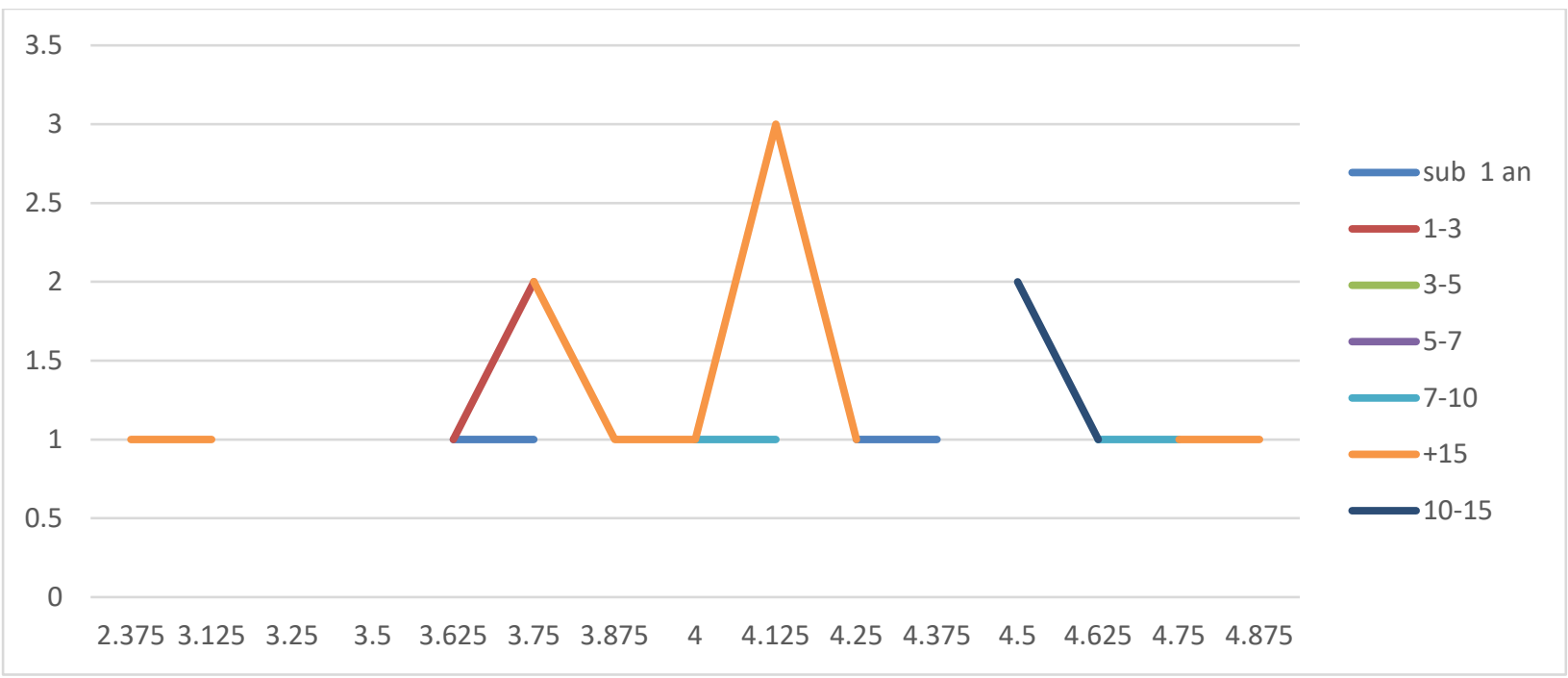

Figura nr.6- Distribuția scorurilor la scala de auto-eficacitate raportată la experiența profesională a terapeuților

Pe baza scorurilor medii obținute la scala de auto-eficacitate, în relație cu experiența profesională este indicată $\mathrm{o}$ raportare crescătoare de la debutul în profesie la experiența în profesie. Media cea mai mică o au terapeuții care au o vechime sub 1 an, $\mathrm{M}=3,8(\mathrm{SD} \pm .868)$, iar valoarea cea mare în perceperea auto-eficacității o au terapeuții cu peste 15 ani vechime, cu o $\mathrm{M}=4.59$ (SD \pm .536$)$. Interesant de observat este și faptul că în perioada de experiență profesională situată între 3-5 ani nivelul auto-eficacității percepute are valoare cea mai mică din plaja de experiență profesională $\mathrm{M}=3.68(\mathrm{SD} \pm .425)$.

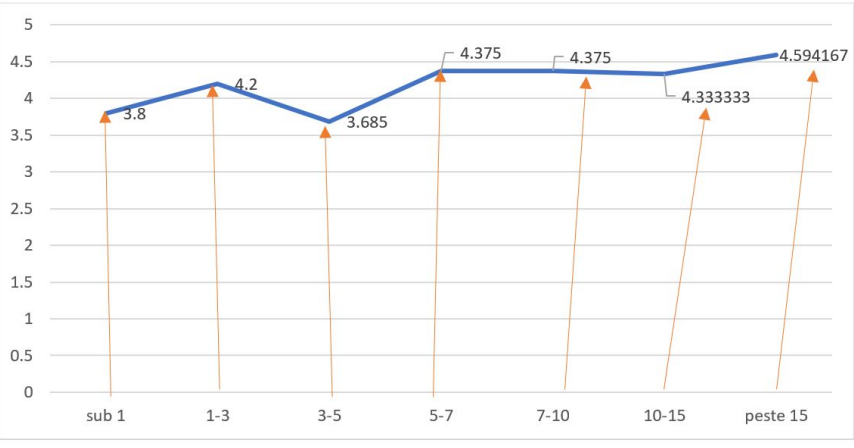

Figura $n r 7$ Rezultatele medii la SAC relaționate la experiența profesională a terapeuților

\section{Rezultatele oltitinute în relația dîntre auto- compasiune și vârstă paciențillor.}

Pe baza rezultatelor prezentate în graficul nr 5 se poate observa că cele mai crescute scoruri la scala de auto-compasiune o înregistrează vârstele înaintate, în intervalul de vârstă -51-6o de ani, cu o medie de $M=4,01$ urmată vârsta de 41-50 de ani, cu o medie de $M=3,90$. Cele mai mici valori înregistrate de terapeuți la scala de auto-compasiune aparține grupei de vârstă a terapeuților aflați între 20 și 30 de ani. 


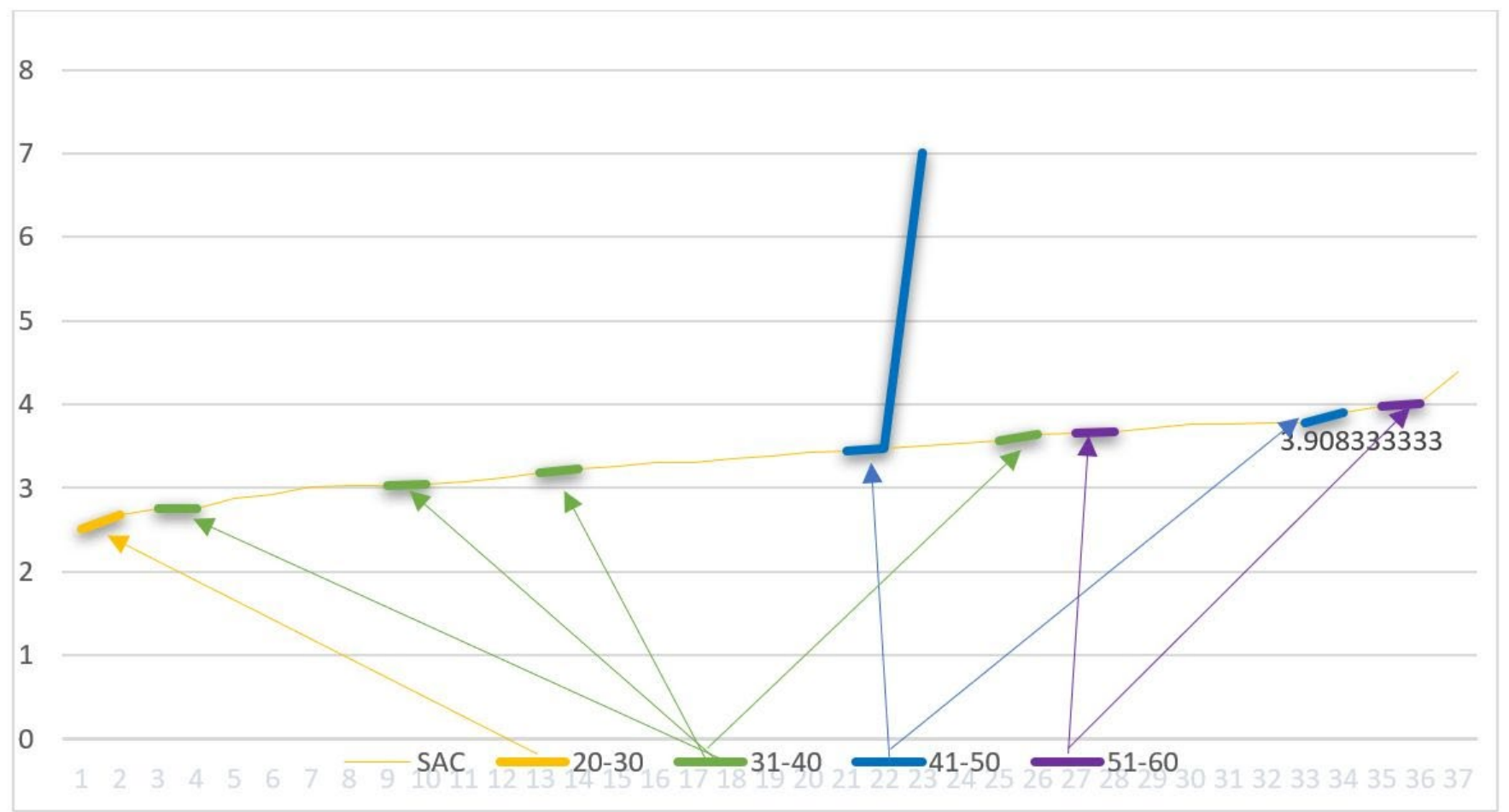

Figura nr 8 - Distribuția răspunsurilor la SAC relaționată la vârsta participanților Cel mai mare nivel al SCS este între 40-50 ani

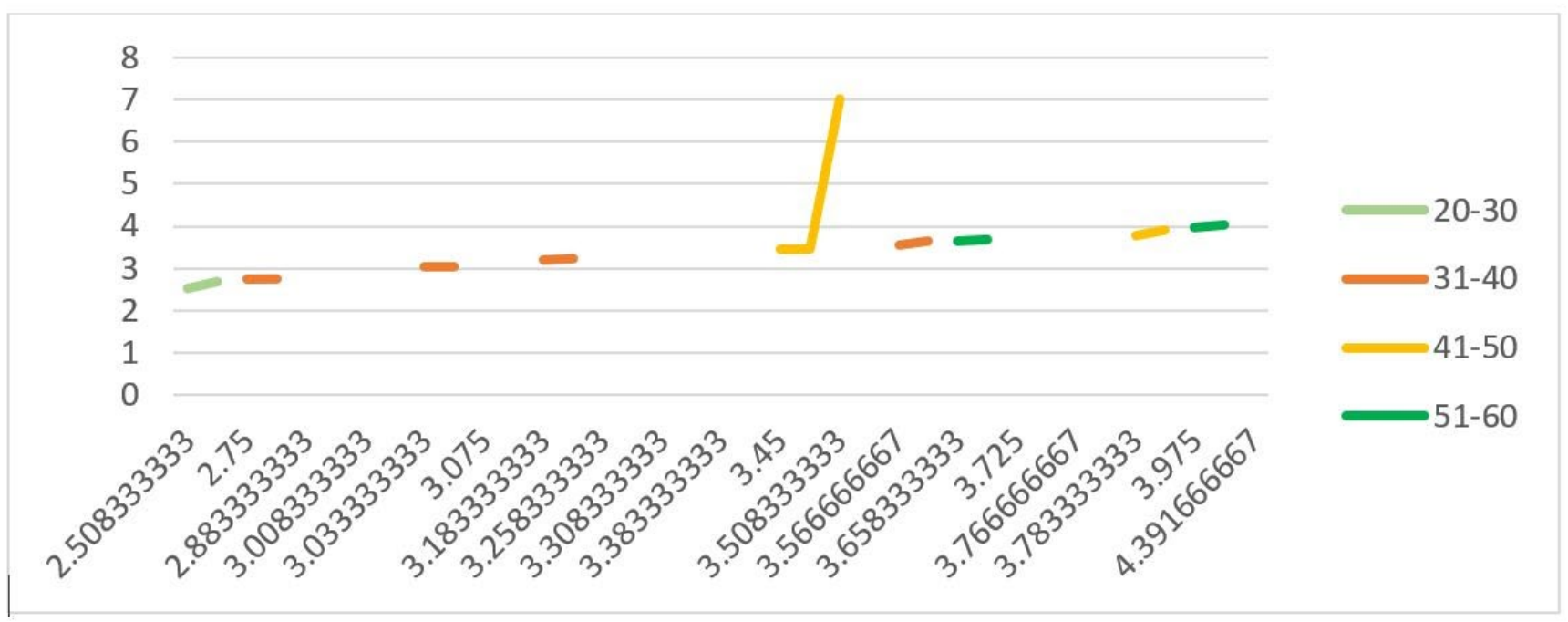

Figura nr 9 - Distribuția răspunsurilor la scala de SAC în funcție de vârsta participanților 
Relația se păstrează și în cazul analizei dintre rezultatele obținute la scala de auto-compasiune și experiența profesională a psihoterapeuților. La începutul activării în profesie terapeuții sunt mai puțin compasivi cu propria lor persoană, apoi se remarcă un trend ascendent pentru ca undeva în perioada 710 ani să se observe o scădere a mediei, iar apoi o creștere a nivelului de autocompasiune către valori mari

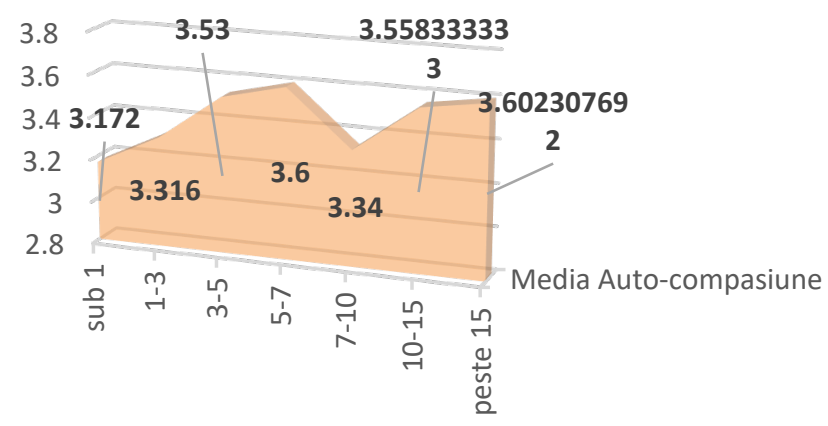

Figura nr 10 - Media răspunsurilor la SAC raportată la experiența profesională

\section{Discuții}

În cazul categoriei profesionale investigate, cea a terapeuților, s-a constatat că există relații între cele două constructe, cel de auto-eficacitate, conform încadrării conceptuale definite de Albert Bandura (Bandura, 1997), operaționalizate prin scala propusă de Chen și colaboratorii (Chen et al., 2001) și auto-compasiunea, așa cum a fost încadrată conceptual și cuantificată de Kristin Neff (K. D. Neff et al., 2020). Această relație are implicații profesionale, mai ales în situații stresante, atunci când apelul la resursele personale este ridicat.
Percepția stresului raportată la profesia de terapeut și implicit necesitatea monitorizării surselor stresante au fost subliniate cu mulți ani în urmă (Farber, 1983; Hellman et al., 1987) și continuă să fie o preocupare actuală. Terapeuții trebuie să fie empatici și compasivi prin natura profesiei pe care o exercită, dar în același timp să fie alerți și sensibili la acele surse particulare de stres care îi afectează și la natura relației terapeutice, să fie orientați către protecția propriei persoane și să își permită să manifeste grijă și compasiune față de persoana lor.

Rezultatele prezentului studiu converg $\mathrm{cu}$ alte rezultate publicate anterior. Spre exemplu într-un studiu realizat de Medeiros și colaboratorii (Medeiros \& Prochaska, 1988) între strategiile de coping pe care psihoterapeuții le foloseau pentru a face față stresului provenit din relația terapeutică se numărau autoreevaluarea și gândirea pozitivă și expectativă, perseverența și optimismul, căutarea liniștii interioare etc. Aceste modalități de coping erau subliniate de către autorii studiului ca fiind eficient și ca fiind folosite de către psihoterapeuții care se auto-percepeau ca având succes. Corelând aceste indicații cu rezultatele studiului prezent, putem constata suprapuneri conceptuale între anumite dimensiuni din scala de auto-compasiune, spre exemplu mindfulness și căutarea păcii interioare din studiu indicat (Medeiros \& Prochaska, 1988), sau între autoeficacitate și succesul în profesie.

Rezultatele obținute la scala de autoeficacitate în cazul terapeuților sunt importante prin prisma implicațiilor. Pentru prezentul studiu terapeuții au obținut scoruri relativ crescute, dar au fost 
și valori minime care indică o percepție redusă a propriei eficacități. În relație cu scala de auto-eficacitate un semnal de alarmă trebuie tras în condițiile existenței unor scoruri scăzute, întrucât acestea indică o percepție scăzută a propriei eficacități, iar în relațiile cu beneficiarii acest lucru are implicații terapeutice. Atunci când terapeutul nu are încredere în propria eficiență, posibilitate ca neîncrederea să se transmită și asupra procesului terapeutic este crescută. Important este însă faptul că rezultatele obținute la scala de auto-eficacitate se relaționează cu vârsta terapeuților, dar și cu experiența profesională. Acest lucru poate fi interpretat prin experiența pe care terapeuții o acumulează. Cu cât au mai multă experiență de viață, și presupunând profesională, terapeuții au sentimente de auto-eficacitate mai crescute.

Analizarea relația dinte SAE si nivelul profesional necesită o anumită atenție. Vedem că la începutul profesiei scorurile de auto-eficacitate sunt mai scăzute, urmând ca pe măsura acumulării de experiență să se fie obținute scoruri mai crescute. Dar interesant este faptul că în primele luni de profesie terapeuții se percep foarte eficienți, iar după primul an se observă o scădere a scorului de autoeficacitate. Acest lucru poate fi explicat prin faptul că la începutul carierei profesionale încrederea în capacitățile proprii este crescută, dar după primul an de profesie aceasta începe să crească. Totuși pe măsură ce se înaintează, la un moment dat auto-eficacitatea percepută începe să fie chestionată, o explicație putând să fie găsită în faptul că în acel interval terapeuții s-au putut bucura și de reușite, dar și de eșecuri în profesie.
Totuși, după ani de experiență profesională, viziunea asupra capacităților proprii începe să crească și să continue un trend ascendent.

Rezultatele obținute la scala de autocompasiune potrivesc și se suprapun $\mathrm{cu}$ cele obținute la scala de auto-eficacitate. Rezultatele converg cu cele obținute de cercetările anterioare asupra autocompasiunii (K. Neff, 2003). Dimensiunile cu valență negativă, auto-critica, izolarea și supra-identificarea sunt la praguri scăzute, iar cele cu valență pozitivă precum umanitatea, auto-compasiunea și auto-bunătatea sunt la nivel superior pe grafic. Acest lucru poate avea impact asupra funcționalității ca individ și ca terapeut. În profesiile care presupun prin natura lor interacțiune umană, empatie și dăruire, un factor de risc îl reprezintă epuizarea resurselor psihice și apariția stării de burn-out. Dacă terapeuții se lasă în afara cercului îngrijirii, oboseala emoțională nu întârzie să se manifeste, iar epuizarea personală apare ca o consecință firească. Printre factori de risc se numără neajutorare și sentiment de ineficiență, iar printre factorii protectivi se numără practicarea tehnicilor de îngrijire și recuperare personală și petrecerea timpului cu prietenii și familia (Zur, 2021). Într-un studiu (Bruschini et al., 2018) desfășurat pe terapeuți din domeniul reabilitării și îngrijirii paliative, s-a observat că profesioniștii în reabilitare prezintă un risc ridicat de epuizare. Există mecanisme comune care stau la baza epuizării în diferitele grupuri profesionale investigate. Concret, factorii de risc identificați au fost epuizarea emoțională $32 \%$, depersonalizarea $13 \%$ și lipsa mulțumirii personale $9 \%$. Similar 
rezultatelor din studiul prezent, în studiul italian (Bruschini et al., 2018) nu s-au constat diferențe de la nivelul factorilor de risc între diferite categoria de terapeuți.

Auto-compasiunea are scoruri mai crescute pe măsură ce terapeuții înaintează în vârstă și în experiența profesională și scoruri mai scăzute la începutul carieri. $\mathrm{O}$ explicație poate consta în faptul că pe măsura dobândirii experienței terapeuții înțeleg că nevoia de auto-protecție este reală, și că izolarea și autocritica funcționează împotriva propriei persoane. Ei înțeleg că pentru a fi eficienți trebuie să fie în egală măsură compasivi cu beneficiarii, dar și cu ei însuși. Rezultatele acestui studiu sunt în relație cu cele identificate de alte studii (Vivino et al., 2009) care susțin că dincolo de empatie este compasiunea și că aceasta ajută la o abordare mai eficientă și lipsită de prejudecăți. Auto-compasiunea presupune și apelul la tehnicile mindfulness, tehnici dovedite utile în psihoterapie (Jennings \& Apsche, 2014; Linehan, 1993) În studiul de față terapeuții au obținut scoruri crescute la dimensiunea de mindfulness, iar acest lucru se poate constitui într-un factor de protecție personală.

\section{Concluzii}

Cele două concepte discutate, cel de autocompasiune și de auto-eficacitate sunt importante în relație cu anumite categorii profesionale și sub auspiciile unor situații considerate stresante și cu încărcătură emoțională crescută. Profesia terapeuților constituie o categorie profesională care se bazează pe compasiune și emoții, iar percepția propriei eficacități influențează actul terapeutic. Studiul de față a a reușit să surprindă modul în care se relaționează auto-compasiune și auto-eficacitatea în cazul terapeuților, dar și relevanța vârstei și a experienței profesionale față de aceste concepte cu implicații și aplicabilitate nu doar teoretică, ci și practică. În final pot fi subliniate câteva aspecte conclusive: (1)Terapeuții tind să aibă valori mari în evaluarea auto-eficacității; (2)Terapeuții tind să aibă valori crescute ale autocompasiunii; (3)Terapeuții tind să aibă nivel ridicat de auto-compasiune și scăzut în cazul auto-criticii așa cum indică subscalele de auto-compasiune; (4) Există o relație directă între auto-eficacitate și auto-compasiune; (5) Terapeuții care au nivel de auto-compasiune crescut au și nivel de auto-eficacitate ridicat, adică au nivel de performanță mai crescut; (6)Nivelul de auto-eficacitate este influențat de vârstă și experiența profesională. (7) Nivelul de autocompasiune este influențat de vârstă și experiența profesională

\section{Bibliografie}

Bandura, A. (1997). Self-efficacy: The exercise of control. Freeman.

Betz, N. E., \& Klein, K. L. (1996). Relationships among measures of career self-efficacy, generalized selfefficacy, and global self-esteem. Journal of Career Assessment. https://doi.org/10.1177/1069072796004 $\underline{00304}$

Bruschini, M., Carli, A., \& Burla, F. (2018). Burnout and work-related stress in Italian rehabilitation professionals: A comparison of physiotherapists, speech therapists and occupational therapists. Work, 59(1), 121-129. https://doi.org/10.3233/WOR-172657 
Chen, G., Gully, S. M., \& Eden, D. (2001). Validation of a New General SelfEfficacy Scale. Organizational Research Methods, 4(1), 62-83. https://doi.org/10.1177/10944281014100 4

Dijkstra, A., \& De Vries, H. (200o). Selfefficacy expectations with regard to different tasks in smoking cessation. Psychology and Health, 15(4), 501-511. https://doi.org/10.1080/088704400084 02009

Farber, B. A. (1983). Psychotherapists' perceptions of stressful patient behavior. Professional Psychology: Research and Practice, 14(5), 697-705. https://doi.org/10.1037/07357028.14.5.697

Gilbert, P. (2020). Compasiunea și mintea umană. Curtea Verche Publishing.

Hellman, I. D., Morrison, T. L., \& Abramowitz, S. I. (1987). Therapist experience and the stresses of psychotherapeutic work. Psychotherapy, 24(2), 171-177. https://doi.org/10.1037/hoo85701

Jennings, J. L., \& Apsche, J. A. (2014). The evolution of a fundamentally mindfulness-based treatment methodology: From DBT and ACT to MDT and beyond. International Journal of Behavioral Consultation and Therapy, 9(2), $1-3$. https://doi.org/10.1037/ho10099o

Linehan, M. (1993). Skills training manual for treating borderline personality disorder. Guilford Press.

Medeiros, M. E., \& Prochaska, J. O. (1988). Coping Strategies That Psychotherapists Use in Working With
Stressful Clients. Professional Psychology: Research and Practice, 19(1), 112-114.

https://doi.org/10.1037/07357028.19.1.112

Neff, K. (2003). Self-Compassion: An Alternative Conceptualization of a Healthy Attitude Toward Oneself. Self and Identity, 2(2), 85-101. https://doi.org/10.1080/1529886030903 $\underline{2}$

Neff, K. (2021). Self-Compassion. https://self-compassion.org/

Neff, K. D., Tóth-Király, I., Knox, M. C., Kuchar, A., \& Davidson, O. (2020). The Development and Validation of the State Self-Compassion Scale (Longand Short Form). Mindfulness. https://doi.org/10.1007/s12671-02001505-4

SPARQtools. (2021). New General SelfEfficacy Scale | SPARQtools. http://sparqtools.org/mobilitymeasure/new-general-self-efficacyscale/\#all-survey-questions

Tăut, D., \& Băban, A. (2008). Examination of the relationship between selfregulatory strategies and healthy eating patterns in coronary heart disease patients. The relevance of compensatory health beliefs. Cogniţie Creier Comportament, 12(2), 219-231.

Vivino, B. L., Thompson, B. J., Hill, C. E., \& Ladany, N. (2009). Compassion in psychotherapy: The perspective of therapists nominated as compassionate. Psychotherapy Research, $\quad$ 19(2), 157-171. https://doi.org/10.1080/1050330080243 $\underline{0681}$ 
Zur. (2021). Therapist Burnout: Facts, Causes and Prevention. https://www.zurinstitute.com/clinicalupdates/burnout-therapists/

\section{Disclaimer}

Autorii indică faptul că nu există conflicte de interese în derularea și publicarea prezentului studiu. Rezultate parțiale și preliminarii au fost prezentate sub formă de lucrare orală la Congresul Național de Psihiatrie - Ediția XIII.

\section{Acknowledgements:}

This work was supported by the grant Partnership for the transfer of knowledge in biogenomics applications in oncology and related fields BIOGENONCO, Project co-financed by FEDR through Competitiveness Operational Programme 2014-2020, contract no. 10/01.09.2016.

1*. Asistent universitar dr. Disciplina de Psihologie Medicală, Universitatea de Medicină și Farmacie „Iuliu Hațieganu” Cluj-Napoca,

Email: raluca.trifu@umfcluj.ro

${ }^{2 *}$ Asistent universitar dr, Disciplina Psihologie Medicală, Universitatea de Medicină și Farmacie „Iuliu Hațieganu” Cluj-Napoca, medic specialist psihiatrie pediatrică. Autor corespondent.

\section{Email:bogdana.miclea@umfcluj.ro}

bogdanamilea@yahoo.ro

3 Șef de lucrări disciplina Psihologie medicală, Universitatea de Medicină și Farmacie „Iuliu Hațieganu” Cluj-Napoca, medic specialist psihiatrie pediatrică

4 Psiholog, Cabinet individual de Psihologie Smaranda Pușcașu

5 Conferențiar, Departamentul de Psihopedagogie Specială, Facultatea de Psihologie și Științele Educației, UBB Cluj

*Corespondent
6. Conferențiar, Disciplina de Psihologie Medicală, Universitatea de Medicină și Farmacie „Iuliu Hațieganu” Cluj-Napoca. Șef. Clinică Psihatrie nr. III. Spitalul Clinic Județean. 